\title{
Analysis of trace elements in Turkish raki by differential pulse polarography
}

\author{
Sukru Kalayci*, Sinan Muhammet \\ Gazi University, Vocational School of Technical Sciences, Department of chemistry, Ankara, Turkey \\ *E-mail: skalayci@gazi.edu.tr
}

Received: 3 June 2021 / Accepted: 10 July 2021 / Published: 10 August 2021

Raki is a traditional Turkish drink. It is obtained by distillation process after suma (alcoholic water) obtained from raisins is sweetened with anise (pinpinella anisum). The quality of raki depends on the quality of the grapes used in the production process and technological differences. In this study, in order to ensure consumer food safety, 10 different raki samples in Turkey were thawed by microwave cracking system, and their trace element content was examined. Differential pulse polarography (DPP), which has high selectivity and sensitivity, was used for the measurements. Appropriate measurement conditions were determined for each element. Validation of the method was done with a known sample. The detection limit of the method was determined as $0.1{\mu \mathrm{gg}^{-1}}^{-}$The amounts of $\mathrm{Fe}, \mathrm{Cu}, \mathrm{Pb}, \mathrm{Cd}, \mathrm{Cr}, \mathrm{As}, \mathrm{Ni}$, $\mathrm{Zn}$, Se elements in the raki samples were determined as approximately $2-80 \mu \mathrm{gg}^{-1}$.

Keywords: Raki, Differential pulse polarography (DPP), Analysis, Some element.

\section{$\underline{\text { FULL TEXT }}$}

(C) 2021 The Authors. Published by ESG (www.electrochemsci.org). This article is an open access article distributed under the terms and conditions of the Creative Commons Attribution license (http://creativecommons.org/licenses/by/4.0/). 